\title{
Analysis of a training program for older workers in the use of technology: difficulties and satisfaction
}

Taiuani Marquine Raymundo' (ID Carla da Silva Santana Castro² $1 \mathrm{D}$

\section{Abstract}

Objective: To analyze the potential of individualized training in the use of technology in the work environment as well as the satisfaction of workers with such training. Method: A quantitative, descriptive, interventional and longitudinal study was performed. Workers aged 50 and over, who performed any type of work activity and who had difficulties using technology participated. The following instruments were used for data collection: a socioeconomic questionnaire, a questionnaire about the technology used in the work environment and difficulties with its use and a scale to evaluate user satisfaction with training. The training sessions used the Client-Centered Practice approach. The data were analyzed by means of descriptive statistics and compared using the McNemar test. Results: A total of 30 workers participated in the study (15 men and 15 women), who were aged between 50 and 75 years and had a mean age of 63.3 years $( \pm 7.89)$. The participants had the most difficulty using computers, cell phones, the internet, email and recording and playback devices. After the training, participants exhibited significantly less difficulty in using cell phones $(p$-value $<0.01)$, computers $(p$-value $<0.01)$, copiers $(p$-value $=0.03)$, the internet $(p$-value $=0.04)$, e-mail $(p$-value $=0.02)$ and recording and playback devices ( $p$-value $=0.04)$. They were satisfied with the training program, the instructor and with their own performance. Conclusion: The results of the present study indicate the potential of individualized training focused on the needs and interests of older workers so that they can perform work activities involving technology with autonomy and independence.
Keywords: Technology. Work. Aging. Training.

\footnotetext{
Universidade Federal do Paraná (UFPR), Departamento de Terapia Ocupacional. Curitiba, PR, Brasil.

2 Universidade de São Paulo (USP), Faculdade de Medicina de Ribeirão Preto (FMRP), Departamento de Ciências da Saúde, Programa de Pós-Graduação Interunidades em Bioengenharia EESC/FMRP/ IQSC - USP. Ribeirão Preto, SP, Brasil.
}

Research Funding: Coordenação de Aperfeiçoamento de Pessoal de Nível Superior - Brasil (CAPES) - Código de Financiamento 001. Phd scholarship.

The authors declare there are no conflicts of interest in relation to the present study. 


\section{INTRODUCTION}

Over the past 50 years, the age structure of the Brazilian population has undergone profound changes, which has had a significant impact on the age distribution of the population, with a decrease in the youth segment and an increase in the adult and older adult groups. As a consequence of such population aging there is also aging of the economically active population (EAP) and the working age population (WAP), the result of the declining entry of young people into the labor market, and the permanence of older workers in the same'.

According to research by the Brazilian Institute of Geography and Statistics (or IBGE) ${ }^{2}$, which described the main highlights of the evolution of the labor market in metropolitan regions, despite a strong concentration in the group of people aged from 25 to 49 years, it is only the participation of the 50 and over age group that has been increasing. This behavior follows population aging. From 2013 to 2015 , the proportion of the WAP aged 50 years or older increased by $9.2 \%$, in contrast to the other age groups, which suffered a decline ${ }^{2}$.

There are a number of factors that influence a person's decision to continue working longer, including their own financial needs or the needs of family members (many older adults are family breadwinners); psychological needs; social interaction and participation; the desire to feel active; the meaning and importance of work in workers' lives; compliance with requirements and to save for retirement ${ }^{3,4}$. Another factor that can influence people's permanence in the labor market is the change in social security and retirement rules, which are constantly under discussion ${ }^{5}$.

The social trends indicated suggest that, year after year, a greater number of older workers will become part of the labor market and, therefore, strategies will be needed to maximize the productivity, health, safety and well-being of these individuals. The lack of proper planning in the near future may result in a shortage of labor and skills ${ }^{6}$.

The changes in the $21^{\text {st }}$ century working environment have created new requirements for the knowledge, skill and capacities of workers. Technological innovations have led to continuous and rapid changes in such environments. Such changes bring with them concerns about the ability of older workers to adapt to this new reality, as, in most cases, the technology available today was not part of the environment of workers aged 50 years or over. In addition, technological changes in the form of the expansion of information technology optimize the speed and space (geographic) of information, resulting in direct impacts on the relational dimensions of individuals and work ${ }^{6,7}$.

Therefore, workers will have to continually adapt to these changes resulting from globalization and advances in information technology. The reduction of differences in professional skills, especially in relation to rapid technological advances, can be achieved through the provision of training and lifelong learning programs ${ }^{6,8}$. Training programs can enable older workers to improve their skills and continue to perform their duties satisfactorily ${ }^{9-11}$.

Training modalities and techniques are also recommended to improve the performance of young adults, as well as older people. The exception concerns the improvement of the development of practical activities in relation to the conceptual training of older adults ${ }^{12}$. Thus, it is essential to provide access to training and ensure that training programs are tailored to the needs and preferences of those who receive them so that there is "successful learning".

In view of the above, the present study aimed to analyze the potential of individualized training for the use of technology in the workplace, as well as the satisfaction of workers with this training.

\section{METHOD}

A study with a quantitative, descriptive, interventional and longitudinal approach was performed, consisting of three phases: pre-training, training and post-training. This study is part of a doctoral thesis entitled Use of technological equipment and information and communication technolog y by workers aged 50 or over in their work activities: impact of training. Data were collected between July 2015 and December 2016. 
The study included individuals aged 50 years and over, who performed work activities, paid or unpaid, used Technological Devices (TD) and Information and Communications Technology (ICT) at work and who had difficulty using the same. Participants could be of either sex, of any marital status, any socioeconomic class, have a minimum education of four years of schooling, not suffer cognitive deficits according to the Mini-Mental State Examination (MMSE), not have neuromotor disabilities, but have visual impairments, provided they were corrected.

The sampling was based on intentional selection for convenience. For the sample to be homogeneous, six strata were created. The strata were balanced and composed of five participants each, giving a total, at the end of the study, of 30 participants (Stratum 1: men aged between 50 and 59 years; Stratum 2: women aged between 50 and 59 years; Stratum 3: men aged between 60 and 69 years; Stratum 4: women aged between 60 and 69 years; Stratum 5: men aged between 70 and 79 years; Stratum 6: women aged between 70 and 79 years). The study from which this manuscript originated relied on a mixed, qualitative-quantitative approach. Thus, the exhaustion/saturation of information strategy was applied, which explains the sample size. Only the quantitative data is provided in this manuscript.

The recruitment of participants was carried out through invitation and dissemination via electronic media, at the Universidade Federal do Paraná (UFPR) and, also, by recommendation. The training was carried out at UFPR, in the Occupational Therapy department. To meet the selection criteria, the participants were submitted to the MMSE ${ }^{13}$ and the cut-off point proposed by Bertolucci et al. ${ }^{14}$ was adopted.

To characterize the sample, the selected participants answered a socioeconomic questionnaire. In the pre-training phase, a questionnaire about the TD and ICT used in the work environment, the specific difficulties in using the same and the degree of difficulty (none, some and high) was applied. This was developed by the author of the present study based on the questionnaire on experience with computers and technology developed by the Center for Research and Education on Aging and
Technology Enhancement ${ }^{15}$. From a list, participants identified which TD and ICT they used at work, stated whether or not they had difficulty using the same, and what the degree of difficulty was. Participants could enter TD and ICT that were not included in the list.

The training was carried out at the Occupational Therapy Department of the Universidade Federal do Paraná and, when necessary, at the participants' own workplace. The approach used in the training was the Client Centered Practice (CCP), which recognizes the subject's autonomy, their need to choose what they need and want to learn themselves, and their recognition of what difficulties affect their work performance ${ }^{16-19}$. The training programs were designed individually, and the duration, frequency and number of sessions were defined according to the needs of each participant.

In addition, the structure, planning and development of the training were based on: prior knowledge about TD and/or ICT; aspects related to the aging process; adaptation of the environment to the needs of the participants; specific pedagogical practices based on the needs and learning pace of each participant; logical sequence of contents; practical exercises to revise and memorize content and generalize learning ${ }^{20}$.

The instructional materials were constructed throughout each session, individually, with letters of appropriate size and font; spacing between sentences; step-by-step functions; real illustrations; and simple language and reduced technical terms.

In the post-training phase, participants answered the Scale on user satisfaction with training, developed based on three other instruments: the scale of reaction to instructional procedures (revalidated in Brazil by Zerbini and Abbad) ${ }^{21}$; the scale of reaction to tutor performance (developed and validated in Brazil by Zerbini and Abbad) ${ }^{22}$; and the scale of reaction to results (developed and validated in Brazil by Borges-Ferreira) ${ }^{23}$.

The scale applied in this study was divided into three items: A) training assessment, consisting of nine questions (11 Likert scale; $0=$ poor and 10=excellent); 
B) assessment of tutors/trainers, composed of 14 questions (11 Likert scale; $0=$ never and $10=$ always); C) contribution of training for the participant, consisting of three questions (11 Likert scale; $0=$ none and $10=$ many). The evaluations of the results of the three items that make up the scale was carried out separately. For the analysis of general satisfaction, the total of each item on the scale was added. The higher the grade, the greater the satisfaction with the training (average values between 0 and 4 indicate little satisfaction; between 4.1 and 7 moderate satisfaction and, between 7.1 and 10 a great deal of satisfaction) ${ }^{24}$.

Also in this phase, for comparison, the participants completed the questionnaire about the TD and ICT used in the work environment again. Socioeconomic data, data related to the TD and ICT used by the research participants, their degree of difficulty and satisfaction with training were analyzed using the descriptive statistics method.

To verify the potential of the training, that is, changes or otherwise in the degree of difficulty presented by the participants before and after training, the McNemar test was proposed. The analyzes were performed using the SAS 9.2 software and a significance level of 5\% was adopted. All instruments, as well as the training, were carried out by the first author of this manuscript, during her doctoral research.

This study complied with Resolution no 466/2012 and Resolution n $n^{\circ}$ 510/2016 and was approved by the Research Ethics Committee of the Clinical Hospital of the Ribeirão Preto Medical School of the Universidade de São Paulo (HCFMRP/USP), under opinion $\mathrm{n}^{\mathrm{o}}$ 2.383.200. The research participants signed an Informed Consent Form (ICF).

\section{RESULTS}

A total of 30 workers, 15 men and 15 women, aged between 50 and 75, with a mean age of 63.3 $( \pm 7.89)$ participated in the study (Table 1$)$.

Participants also reported their various past and current occupations (university professor; occupational therapist; journalist; business administrator; agronomist; typist; library assistant; financial director; foreign language professor; among others). Of these, eight $(26.7 \%)$ reported having the same occupation up to the date of the study, $11(36.7 \%)$ had changed their occupation, but still performed activities in the same area of knowledge as the previous job, and eight (26.7\%), reported changes both in current work activities and in the area of knowledge, when compared to their previous occupations. Finally, three (10.0\%) of the participants performed the same role, but were hired as "senior employees" due to being retired. In relation to current occupation, 16 (53.3\%) worked full time and four $(13.3 \%)$ worked part time, five $(16.7 \%)$ were selfemployed, three $(10.0 \%)$ were volunteers and two $(6.7 \%)$ worked according to demand.

The TD and ICT most used by participants in the work environment were computers; cell phones; photocopiers; the internet; email; printer; and recording and playback devices (CD, DVD and pen drive). The greatest difficulties were reported in the use of computers, cell phones, the internet, e-mail and recording and reproduction devices (Table 2 ). 
Table 1. Characterization of sample (N=30). Curitiba, Paraná, 2017.

\begin{tabular}{lll}
\hline Socioeconomic Characteristics & Men & Woman \\
\cline { 3 - 3 } Marital status & $\mathrm{n}(\%)$ & $\mathrm{n}(\%)$ \\
Single & $0(0.0)$ & $2(6.7)$ \\
Married & $13(43.3)$ & $4(13.3)$ \\
Divorced & $2(6.7)$ & $6(20.0)$ \\
Widowed & $0(0.0)$ & $3(10.0)$ \\
Years of schooling & & \\
4 to 8 & $0(0.0)$ & $1(3.3)$ \\
9 to 11 & $2(6.7)$ & $5(16.7)$ \\
12 to 15 & $4(13.3)$ & $2(6.7)$ \\
More than 15 & $9(30.0)$ & $7(23.3)$ \\
Income $(\mathrm{R} \$)$ & & $0(0.0)$ \\
From 1,301 to 2,600 & $1(3.3)$ & $2(6.7)$ \\
From 2,601 to 3,900 & $1(3.3)$ & $4(13.3)$ \\
From 3,901 to 5,200 & $1(3.3)$ & $9(30.0)$ \\
Above 5,201 & $12(40.0)$ & \\
\hline
\end{tabular}

Table 2. Technological Devices (TD) and Information and Communication Technology (ICT) used in the work environment and associated degree of difficulty. ( $\mathrm{N}=30)$. Curitiba, Paraná, 2017.

\begin{tabular}{|c|c|c|c|c|}
\hline \multirow[b]{2}{*}{ TD and ICT } & \multicolumn{4}{|c|}{ Degree of difficulty* } \\
\hline & $\begin{array}{l}\text { Participants that } \\
\text { used them at work } \\
(\%)\end{array}$ & $\begin{array}{l}\text { No } \\
\text { Difficulty } \\
\mathrm{n}(\%)\end{array}$ & $\begin{array}{l}\text { Some } \\
\text { Difficulty } \\
\mathrm{n}(\%)\end{array}$ & $\begin{array}{l}\text { A Lot of } \\
\text { Difficulty } \\
\mathrm{n}(\%)\end{array}$ \\
\hline Cell phone & $22(73.3)$ & $4(18.2)$ & $12(54.5)$ & $6(27.3)$ \\
\hline Fax & $5(16.7)$ & $2(40.0)$ & $3(60.0)$ & $0(0.0)$ \\
\hline Computer & $30(100.0)$ & $1(3.3)$ & $22(73.3)$ & $7(23.3)$ \\
\hline Photocopier / Scanner & $25(83.3)$ & $9(36.0)$ & $13(52.0)$ & $3(12.0)$ \\
\hline Internet & $29(96.7)$ & $7(24.1)$ & $20(69.0)$ & $2(6.9)$ \\
\hline Email & $29(96.7)$ & $9(31.0)$ & $18(62.1)$ & $2(6.9)$ \\
\hline Printer & $27(90.0)$ & $16(59.3)$ & $10(37.0)$ & $1(3.7)$ \\
\hline Card machine & $5(16.7)$ & $5(100.0)$ & $0(0.0)$ & $0(0.0)$ \\
\hline Cash machine & $10(33.3)$ & $8(80.0)$ & $2(20.0)$ & $0(0.0)$ \\
\hline Barcode reader & $5(16.7)$ & $4(80.0)$ & $1(20.0)$ & $0(0.0)$ \\
\hline Telephone exchange & $10(33.3)$ & $6(60.0)$ & $4(40.0)$ & $0(0.0)$ \\
\hline Tablet & $6(20.0)$ & $3(50.0)$ & $1(16.7)$ & $2(39.3)$ \\
\hline Recording and playback devices & $24(80.0)$ & $6(25.0)$ & $16(66.7)$ & $2(8.3)$ \\
\hline Multimedia projector & $8(26.7)$ & $2(25.0)$ & $5(62.5)$ & $1(12.5)$ \\
\hline GPS & $1(3.3)$ & $0(0.0)$ & $0(0.0)$ & $1(100.0)$ \\
\hline Bluetooth & $1(3.3)$ & $0(0.0)$ & $0(0.0)$ & $1(100.0)$ \\
\hline
\end{tabular}

${ }^{*}$ The percentage was calculated considering the total number of participants who reported using each TD or ICT as $100 \%$; GPS=Global Positioning System. 
Due to the variation in the difficulties presented by the participants and considering the methodology adopted in the training, the number and duration of the sessions were different for each participant. Practical classes, ranging from 45 to 120 minutes, were held between once and twice a week, and the number of sessions ranged from one to 19. This variation was often related to greater difficulty in retaining information; differences in the pace of learning; little time available for training; and the need to review the content at the beginning of each new session, which eventually increased the duration of these.

According to the responses of the participants after the training, the most used TD and ICT in the workplace were the same as previously reported, and the TD and ICT that the participants reported the greatest degree of difficulty with were cell phones $(\mathrm{n}=16 ; 55.0 \%)$, computers $(\mathrm{n}=17 ; 56.6 \%)$ and tablets $(n=18 ; 60.0 \%)$. In the comparison between the pretraining and post-training phases, a significant effect of the training performed was observed.

A significant reduction in the degree of difficulty was observed in the use of the following TD and ICT: cell phones $(63.2 \%$; $p$-value $<0.01)$; computers $(60.0 \%$; $p$-value $<0.01)$; recording and reproduction devices $(53.0 \%$; $p$-value $=0.04)$; photocopiers $(45.0 \%$; $p$-value $=0.03)$; e-mail $(43.4 \%$; $p$-value $=0.02)$; and the internet $(39.3 \%$; $p$-value $=0.04)$ (Table 3). For other TD and ICT the participants also exhibited a reduction in the degree of difficulty, although the effect of training in this technology was not significant.

Table 3. Reduction in the degree of difficulty of participants in the use of cell phones, computers, photocopiers, the internet, e-mail and recording and reproduction devices: pre and post training. Curitiba, Paraná, 2017.

\begin{tabular}{|c|c|c|c|c|}
\hline TD/ICT & $\begin{array}{l}\text { No Difficulty } \\
\%\end{array}$ & $\begin{array}{l}\text { Some Difficulty } \\
\%\end{array}$ & $\begin{array}{l}\text { A Lot of Difficulty } \\
\%\end{array}$ & $p$ \\
\hline Cell phone (pre-training) & \multicolumn{3}{|c|}{ Cell phone (pre-training) } & \multirow{4}{*}{$<0,01$} \\
\hline No difficulty & 10.5 & 0.0 & 0,0 & \\
\hline Some difficulty & 31.6 & 26.3 & 0,0 & \\
\hline A lot of difficulty & 0.0 & 31.6 & 0,0 & \\
\hline Computer (pre-training) & \multicolumn{3}{|c|}{ Computer (pre-training) } & \multirow{4}{*}{$<0,01$} \\
\hline No difficulty & 0.0 & 3.3 & 0 & \\
\hline Some difficulty & 36.7 & 33.3 & 3,3 & \\
\hline A lot of difficulty & 6.7 & 16.7 & 0,0 & \\
\hline Photocopier (pre-training) & \multicolumn{3}{|c|}{ Photocopier (pre-training) } & \multirow{4}{*}{0,03} \\
\hline No difficulty & 35.0 & 0.0 & 0,0 & \\
\hline Some difficulty & 45.0 & 20.0 & 0,0 & \\
\hline A lot of difficulty & 0.0 & 0.0 & 0,0 & \\
\hline Internet (pre-training) & \multicolumn{3}{|c|}{ Internet (pre-training) } & \multirow{4}{*}{0,04} \\
\hline No difficulty & 21.4 & 3.6 & 0,0 & \\
\hline Some difficulty & 35.7 & 32.1 & 0,0 & \\
\hline A lot of difficulty & 0.0 & 3.6 & 3,6 & \\
\hline E-mail (pre-training) & \multicolumn{3}{|c|}{ E-mail (pre-training) } & \multirow{4}{*}{0,02} \\
\hline No difficulty & 28.6 & 3.6 & 0,0 & \\
\hline Some difficulty & 39.3 & 21.4 & 0,0 & \\
\hline A lot of difficulty & 3.6 & 3.6 & 0,0 & \\
\hline $\begin{array}{l}\text { Recording and reproduction devices } \\
\text { (pre-training) }\end{array}$ & \multicolumn{3}{|c|}{$\begin{array}{l}\text { Recording and reproduction devices } \\
\text { (pre-training) }\end{array}$} & \multirow{4}{*}{0,04} \\
\hline No difficulty & 29.4 & 0.0 & 0,0 & \\
\hline Some difficulty & 47.1 & 17.7 & 0,0 & \\
\hline A lot of difficulty & 0 & 5.9 & 0,0 & \\
\hline
\end{tabular}

$\mathrm{TD}=$ technological devices; ICT=information and communication technology. 
Regarding the satisfaction of the participants with the training, in the individual analysis of the first item as a whole (satisfaction of the participants in relation to the training itself and the techniques covered), the score of the participants' responses in relation to the nine questions varied between $5.8 \%$ and $10.0 \%$, with one participant describing moderate satisfaction and the rest of the sample exhibiting a great deal of satisfaction. In the second item (participants' satisfaction in relation to the trainer), the score of the answers, in relation to the 14 questions, varied between $7.9 \%$ and $10.0 \%$, meaning that all the participants reported a great deal of satisfaction in relation to this scale item. In the analysis of item three (satisfaction of the participants in relation to the contribution of training to their personal lives), composed of three questions, the score of the answers varied between $6.3 \%$ and $10.0 \%$, with three participants reporting moderate satisfaction and the others, a great deal of satisfaction (Table 4).

The score of the responses of all participants for each question ranged from $8.6 \%$ to $9.5 \%$ for the first item on the scale, from $9.3 \%$ to $9.7 \%$ for item two, and from $8.6 \%$ to $9.1 \%$ for item three. Thus, in general, the participants were very satisfied in relation to the three items evaluated on the scale and in relation to training as a whole.
Among the items listed by the participants in relation to satisfaction with the training, those that received higher scores were: the language used in the training material; the link between the proposed content and the training objectives; the link between the training content and the personal goals of the individual; guidance for solving errors in revision exercises; amount of content for each proposed theme. The lowest scores were in relation to: revision exercises and activities proposed at the end of the modules.

In relation to the trainer, higher grades were attributed to the items: he/she respected my learning pace; used language that was easy to understand; was always available and willing to help in question sessions (the researcher made herself available to answer questions from participants at times other than those intended for training); he/she considered the ideas of the participants; he/she changed the way of explaining until there was complete understanding.

As for the satisfaction with the contribution of training for the participants themselves, high marks were given and there was consequently a great deal of satisfaction regarding their ability to apply the knowledge taught in the training program in different situations, the assimilation of the course content and the ability to transmit the knowledge acquired in the training to other people (Table 4).

Table 4. Participant satisfaction with training carried out according to each question of the scale $(\mathrm{N}=30)$. Curitiba, Paraná, 2017.

\begin{tabular}{ll}
\hline Satisfaction with training & Mean (standard deviation) \\
\hline 1. Link between the proposed content and the training objectives & $9.3( \pm 0.91)$ \\
2. Link between the training content and personal goals of individual & $9.3( \pm 1.06)$ \\
3. Sequence of presentation of themes & $9.3( \pm 1.15)$ \\
4. Language used in the training material & $9.5( \pm 0.96)$ \\
5. Revision exercises & $8.6( \pm 1.56)$ \\
6. Activities proposed at the end of the modules & $8.9( \pm 1.36)$ \\
7. Guidance for solving errors in revision exercises & $9.3( \pm 1.01)$ \\
8. Amount of content for each proposed theme & $9.2( \pm 0.99)$ \\
9. Question sessions & $9.1( \pm 1.35)$ \\
Total & $9.1( \pm 1.35)$ \\
\hline
\end{tabular}


Continuation of Table 3

\begin{tabular}{|c|c|}
\hline Satisfaction with the trainer & Mean (standard deviation) \\
\hline 1. Encouraged to collectively discuss queries and questions & $9.5( \pm 0.76)$ \\
\hline 2. Tried to understand the reasons that were hindering my participation & $9.5( \pm 0.81)$ \\
\hline 3. Praised my participation in classes and in question sessions & $9.3( \pm 1.18)$ \\
\hline 4. Made constructive criticisms & $9.3( \pm 0.91)$ \\
\hline 5. Always present and willing to help in question sessions & $9.6( \pm 0.72)$ \\
\hline 6. Respected my learning pace & $9.7( \pm 0.64)$ \\
\hline 7. Considered participants' ideas & $9.6( \pm 0.60)$ \\
\hline 8. Praised my performance during the training & $9.4( \pm 0.80)$ \\
\hline 9. Provided answers that fully clarified my doubts & $9.5( \pm 0.76)$ \\
\hline $\begin{array}{l}\text { 10. Used his/her experiences with the themes and with the target population of the } \\
\text { study during classes }\end{array}$ & $9.3( \pm 1.00)$ \\
\hline 11. Used language that was easy to understand & $9.7( \pm 0.60)$ \\
\hline 12. Indicated pathways to solutions instead of giving ready answers & $9.5( \pm 0.67)$ \\
\hline 13. Changed the way of explaining until there was total understanding & $9.6( \pm 0.61)$ \\
\hline 14. Integrated theory and practice in explanations & $9.5( \pm 0.72)$ \\
\hline Total & $9.5( \pm 0.13)$ \\
\hline Satisfaction regarding training contributions for the participant & Mean (standard deviation) \\
\hline 1. Ability to apply the knowledge taught in training in different situations & $9.1( \pm 0.96)$ \\
\hline 2. Assimilation of course content & $9.0( \pm 1.06)$ \\
\hline 3. Ability to transmit the knowledge acquired in the training to other people & $8.6( \pm 1.52)$ \\
\hline Total & $8.9( \pm 0.22)$ \\
\hline Total average of the three items & $9.3( \pm 0.24)$ \\
\hline
\end{tabular}

\section{DISCUSSION}

In general, the results of this study contradicted myths and stereotypes ${ }^{25-27}$ and proved that the participants of this study, after undergoing training that respected their limits, time and interests, were able to learn to use TD and ICT, demonstrating a significant reduction in the difficulty they experienced. It must be remembered, however, that the process of acquiring knowledge and skills to deal with technology was often difficult. In some cases, it took longer than expected for a function to be fully understood.

Literature points out that older workers can achieve learning outcomes equivalent to their younger colleagues, especially if the work content and tasks are designed to use past learning experiences, if sufficient time, practice and motivation are provided, and if age-related issues and the previous knowledge; skills; goals; attitudes; individual values and interests of workers are considered ${ }^{9,20,28}$.
As for the satisfaction of the participants in relation to the training carried out, in the case of the present study, simple, low complexity training, performed individually, with specific duration for each participant, was fundamental for the participants to report experiencing positive satisfaction (a great deal of satisfaction); which complies with the items of impact described in literature to be followed when developing training, such as, for example, the ability of those receiving training to process and apply information, the provision of small amounts of information at a time, personalized materials with content sequencing, step-by-step instructions ${ }^{29}$.

Furthermore, according to literature, for the satisfaction of participants to be guaranteed, it is extremely important that it is developed individually and, when possible, together with the individual to be trained ${ }^{30,31}$. It is essential that current training methods and teaching strategies are understood, and that the perception of older workers about each of these is known ${ }^{30,32}$. On the other hand, although the 
participants of this study were highly satisfied with the material used, a lower score was attributed to the revision exercises item (8.6), which serves as a basis for the future improvement of training, especially in relation to that topic.

On the other hand, in relation to satisfaction with the trainer, the positive evaluations point to the importance that she represented for the effective accomplishment of the training. According to McCausland et al. ${ }^{33}$ as well as trainers having expectations about training participants, these, in turn, have expectations about their coaches and their characteristics. According to Wood et al. ${ }^{34}$, it is important that those responsible for training are sensitive and support older learners when they encounter challenges. The sensitivity of the trainer to the specific needs of the trainees, the flexibility of content, as well as the provision of more time to perform tasks, the provision of pleasant training environments and the use of clear and accessible terminologies are also considered important. ${ }^{34}$.

Satisfaction in relation to the contribution of the training for the participant was associated with the perception of the workers about their abilities. After training, the workers gave high marks and reported a great deal of satisfaction with their ability to apply the knowledge taught in the training in different situations, assimilation of the course content and the ability to transmit the knowledge acquired in the training to others.

Another fact observed fact is that the participants were able to transfer what they learned in training to their workplaces, which, according to a report from the European Center for the Development of Vocational Training (CEDEFOP) ${ }^{35}$, contributes to better experiences and day to day realities for workers in the workplace.

Despite the positive results, the present study presented some difficulties and limitations. One of the difficulties was in relation to the unforeseen circumstances of the participants, such as the time available for training and internal problems in the workplace, such as the non-functioning of equipment, difficulties in accessing the internet and the inability to access certain sites, imposed by the workplace system. In these cases, the work environment was a barrier to the learning requested by the participants. Such facts contributed to the increase in the number of training sessions.

As for the limitations, it is believed that the sample composition, which involved participants with a high level of education and income, may direct the results towards a specific population only. However, it is believed that the present study, even with a small sample size, provides new reflections on the permanence of older workers in the labor market and raises important questions that may be reflected in future studies and research.

\section{CONCLUSION}

The results of the present study indicated a reduction in difficulties in the use of technological devices and information and communication technology among older workers after training involving a simple, low complexity and participantcentered approach. In addition, after the training, the participants reported personal satisfaction, as well as satisfaction with the training.

The present study sought to provide contributions with regard to the gap in Brazilian bibliographic references on this subject. However, it does not exhaust the topic, but it brings to light relevant aspects to be addressed in future studies and research on the theme of the permanence of older workers in the labor market and the use of technology.

It is suggested that future studies involve the realization of training in the use of technology that addresses, instead of an individual program, groups of workers with similar difficulties, so that the results can be compared with, and even complement, the findings of this study. Another suggestion is to apply the study to other population segments (with different levels of education and income). It is also suggested that the view of employers regarding the permanence of older workers in the market is investigated, in order to understand how they are managing these changes, as well as their perception regarding the participation in training of their employees. 
Deepening existing research and exploring areas yet to be studied contributes to the consolidation of the body of knowledge for professionals who are concerned with the skills necessary to use new technology and with the maintenance of older workers in the labor market. Furthermore, they contribute to proving the effectiveness and efficiency of training programs and to pressurize public policies and those of companies and private institutions to include in their agendas the question of population aging in a society in which technology is inexorably imposed.

Edited by: Ana Carolina Lima Cavaletti

\section{REFERENCES}

1. Camarano AA, Kanso S, Fernandes D.

Envelhecimento populacional, perda da capacidade laborativa e políticas públicas brasileiras entre 1992 e 2011[ Internet]. Rio de Janeiro: IPEA; 2013 [acesso em 26 ago. 2018]. Disponível em: http:// www.ipea.gov.br/portal/index.php?option $=$ com content\&view $=$ article\&id $=20491$

2. Instituto Brasileiro De Geografia E Estatística. Sistema IBGE de Recuperação Automática (SIDRA) 2016 [Internet]. Rio de Janeiro: IBGE; 2016 [acesso em 15 out. 2016]. Disponível em: https://sidra.ibge. gov.br/home/ipca15/brasil

3. Ribeiro PCC, Almada DSQ, Souto JF, Lourenço RA. Permanência no mercado de trabalho e satisfação com a vida na velhice. Ciênc Saúde Colet. 2018;23(8):2683-92.

4. AARP Real Possibilities. Staying ahead of the curve 2013: the AARP work and career study [Internet]. Whashington, DC; 2014 [acesso em 26 jan. 2016]. Disponível em: www.aarp.org/content/dam/aarp/ research/surveys_statistics/general/2014/StayingAhead-of-the-Curve-2013-The-Work-and-CareerStudy-AARP-res-gen.pdf

5. Brasil. Lei n. 13.183 de 4 de novembro de 2015. Altera as Leis $n^{\circ}$ s 8.212, no 10.779, $n^{\circ} 12.618, n^{\circ} 10.820$ e a lei $\mathrm{n}^{\circ}$ 7.998. Diário Oficial da União. 5 nov.15. Sec.1:1.

6. Czaja SJ, Sharit J, Charness N, Schmidt AC. The implications of changes in job demands for the continued and future employment of older workers. In: Finkelstein LM, Truxillo DM, Fraccaroli F, Kanfer R. Facing the challenges of multi-age workforce: a use-inspired approach. New York: Routledge; 2015. p.159-79.

7. Lee CC, Czaja SJ, Sharit J. Training older workers for technology-based employment. Educ Gerontol. 2009;35(1):15-31.

8. Souza AC, Melo CVB. O mercado de trabalho brasileiro diante das perspectivas de envelhecimento da população. In: Brasil. Câmara dos Deputados, Centro de Estudos e Debates Estratégicos - Consultoria Legislativa. Brasil 2050: desafios de uma nação que envelhece. Brasília, DF: Edições Câmara; 2017. p.19-42.

9. Ilmarinen J, Ilmarinen V. Work ability and aging. In: Finkelstein LM, Truxillo DM, Fraccaroli F, Kanfer R. Facing the challenges of multi-age workforce: a use-inspired approach. New York: Routledge; 2015. p. 134-56.

10. Fleischmann M, Ferry K. Older workers and employer-provided training in the Netherlands: a vignette study. Ageing Soc. 2018;38(10):1995-2018.

11. Greenan N, Messe PJ. Transmission of vocational skills in the second part of careers: the effect of ICT and management changes. J Labour Market Res 2018;52(6):1-16.

12. Leppel K, Brucker E, Cochran J. The importance of job training to job satisfaction of older workers. J Aging Soc Policy. 2012;24(1):62-76.

13. Folstein MF, Folstein SE, McHugh PR. Mini Mental State: a practical method for grading the cognitive state of patients for the clinician. J Psychiatr Res. 1975;12(3):189-98.

14. Bertolucci PH, Brucki SM, Campacci SR, Juliano Y. The Mini-Mental State Examination in a general population: impact of educational status. Arq Neuropsiquiatr. 1994;52(1):1-7.

15. Czaja SJ, Charness N, Dijkstra K, Fisk AD, Rogers WA, Shari, J. Computer and technology experience questionnaire. In: Center for Research na Education on Aging and Technology Enhancement. CREATE technical report 2006 [Internet]. Illinois: CREATE; 2006 [acesso em 15 ago. 2017]. Disponível em: http://create-center.gatech.edu/publications_db/ report $\% 203 \% 20$ ver1.3.pdf

16. American Occupational Therapy Association. Occupational therapy practice framework: Domain and process. Am J Occup Ther. 2014;68(Suppl.1):1-48.

17. Law M, Baptiste S, Mills J. Client-centred practice: what does it mean and does it make a difference? Can J Occup Ther. 1995;62(5):250-7.

18. Sumsion T, Smyth G. Barriers to client-centredness and their resolution. Can J Occup Ther. 2001;67(1):15-21. 
19. Vaz D, Jubilini L, Queiroz L. Prática centrada no cliente na reabilitação: definição, instrumentos e desafios. Rev Ter Ocup. 2017;28(1):122-7.

20. Czaja SJ, Sharit J. Designing training and instructional programs for older adults. Boca Raton: CRC Press; 2012.

21. Zerbini T, Abbad G. Reação aos procedimentos instrucionais de um curso via internet: validação de uma escala. Estud Psicol. 2009:26(3):363-71.

22. Zerbini T, Abbad G. Reação ao desempenho do tutor em um curso a distância: validação de uma escala. Estud Pesqui Psicol. 2009;9(2):447-63.

23. Borges-Ferreira MF. Avaliação de reações e aprendizagem em disciplinas de curso técnico profissionalizante oferecidas a distância [dissertação]. Brasília, DF: Universidade de Brasília, Instituto de Psicologia; 2005.

24. Zerbini T, Borges-Ferreira MF, Abbad GS. Medidas de reação a cursos a distância. In: Zerbini T, Mourão L, Abbad GS. Medidas de avaliação em treinamento, desenvolvimento e educação: ferramentas para gestão de pessoas. Porto Alegre: Artmed; 2009. p. 91-107.

25. Vasconselos AF. The contemporary experience of work: older workers' perceptions. Manag Res Rev. 2015;38(4):381-403.

26. Findsen B. Older workers' learning within organizations: issues and challenges. Educ Gerontol. 2015;41(8):582-9.

27. Rego A, Vitória A, Tupinambá A, Reis Júnior D, Reis $\mathrm{D}$, Cunha MP, et al. Brazilian managers' ageism: a multiplex perspective. Int J Manpow. 2018;39(3):414-33.
28. Beier ME. The aging of workforce and the demands of work in the 21st century. In: Finkelstein LM, Truxillo DM, Fraccaroli F, Kanfer R. Facing the challenges of multi-age workforce: a use-inspired approach. New York: Routledge; 2015. p.108-33.

29. Taha J, Czaja SJ, Sharit J. Technology training for older job-seeking adults: The efficacy of a program offered through a university-community collaboration. Educ Gerontol. 2016;42(4):276-87.

30. Chua RLE, Guzman AB. Do You See What I See? Understanding Filipino Elderly's Needs, Benefits, and Expectations from an Adult Continuing Education Program. Educ Gerontol. 2014;40(1):1-15.

31. Zwick T. Training older employees: what is effective? Int J Manpow. 2015;36(2):136-50.

32. Ravichandrana S, Cichy KE, Powers M, Kirby $\mathrm{K}$. Exploring the training needs of older workers in the food service industry. Int J Hosp Manag. 2015;44:157-64.

33. McCausland TC, King EB, Bartholomew L, Feyre R, Ahmad A, Finkelstein LM. The technological age: the effects of perceived age in technology training. J Bus Psychol . 2015;30(4):693-708.

34. Wood E, Lanuza C, Baciu I, MacKenzie M, Nosko A. Instructional styles, attitudes and experiences of seniors in computer workshops. Educ Gerontol. 2010;36(10-11):834-57.

35. European Centre for the Development of Vocational Training. Working and ageing: the benefits of investing in an ageing workforce. Luxembourg: Publications Office of the European Union; 2012. 